\title{
Betulin a pentacyclic tri-terpenoid: an hour to rethink the compound
}

\begin{abstract}
Betulin a pentacyclic triterpenoid member of lupane family occurs widely in numerous plants. Betulin, unlike most other constituents is easily isolated that it can be utilized for various pharmacological actions. It is interesting to know that betulin can be easily extracted from bark, stem, leaves, flower, roots etc. of plant. This review summarizes plethora of reliable pharmacological activities like anti-inflammatory, anti-ulcer, anti-diabetic, anti-bacterial, anti-microbial, anti-malarial, anti-viral, anti hyperlipidaemic, anti-cancer and anti HIV exhibited by betulin and its derivatives. For this it can be utilized in herbal as well as synthetic pharmaceutical industries because of its promising efficacy and low levels of toxicity. Although betulin possess a wide range of pharmacological activities, there is still lack of awareness of its proper utilization in the field of medicine. So, need of the hour is to refocus on naturally occurring betulin and its derivatives to avoid side effects caused by synthetic compounds utilized in treating various ailments. Therefore, the aim of the present review is to re-explore the potential of betulin, as an alternative to the compounds possessing higher side effects.
\end{abstract}

Volume I Issue 2 - 2017

\author{
Amritveer Boparai,' Junaid Niazi,' Neha \\ Bajwa, ${ }^{2}$ Preet Amol Singh ${ }^{3}$ \\ 'Bahra Institute of Pharmacy, Rayat Group of Institutions, \\ Patiala-14700I, Punjab, India \\ ${ }^{2} \mathrm{GVM}$, College of Pharmacy, Haryana, India \\ ${ }^{3}$ Department of Pharmaceutical Sciences and Technology, \\ Maharaja Ranjit Singh Punjab Technical University, Bathinda, \\ Punjab, India
}

\begin{abstract}
Correspondence: Preet Amol Singh, Department of Pharmaceutical Sciences and Technology, Maharaja Ranjit Singh Punjab Technical University, Bathinda, Punjab, India, Pin code |5 100I,Tel+9|-8437000234, Email preetnabha67@gmail.com
\end{abstract}

Received: October 01, 2017| Published: October 18, 2017

Keywords: betulin, pentacyclic triterpenoid, betulinic acid, lupine, pharmacological activities

\section{Introduction}

Mother earth, a bionetwork enriched with plethora of remarkable plants holding numerous beneficial chemical compounds, which play an integral role in maintaining the lives stealth and safe. Betulin lup20 (29)-ene-3ß, 28-diol, a pentacyclictriterpene alcohol with a lupane skeleton is one of such chemical compounds contributing towards the advancement in field of medicine.$^{1-3}$ It is obtained from outer bark of Birch trees. ${ }^{4-6}$ As described in Figure 1: Betulin has a pentacyclic ring structure and hydroxyl groups in positions $\mathrm{C}_{3}$ and $\mathrm{C}_{28}{ }^{7-9}$ Betulin in presence of acid agents undergoes rearrangement to form allobetulin. ${ }^{10}$ It is acknowledged that plants with lupine series are helpful in curing various diseases for this one relies on betulin which on conversion tobetulinic acid, the alcohol group replaced by a carboxylic acid group has more biological activity., 2,,10,11 The alcohol group cannot join with stationary phase because two groups are located on opposite sides of compound. ${ }^{1}$ Betulinic acid, the more bioactive compound exhibits choleritic, antihelmintic, powerful prophylactic, anti-HIV, antimutageneagent, antiviral, anti-fungal, anti-leukemia, anti-leishmanial, anti-inflammatory, immunomodulator., ${ }^{72-15}$

Adding on it acts as anti-parasitic against Plasmodium falciparum and Trypanosomabruceirhodesiense, anti-microbial, anti-obesity by improving the lipid profile, also stabilizes atherosclerotic plaques. ${ }^{15,16-20}$ Betulin is also used as plaster for sterilization of wounds, acts as liver protectant in chronic hepatitis therapy, antirachitic, antitrypanosomal also supports apoptosis i.e. self-destruction of tumor cells. ${ }^{2,7,21,22}$ As betulin is found in various other plants so people of vernacular regions take numerous benefits depending on the necessity. Infusion of red alder is used in lymphatic disorders and tuberculosis. Native Americans use it to mediate insect bites, poison oak, digestive tract infections and skin inflammation. ${ }^{23-26}$ Rather than possessing pharmacological activities, due to elegant bark of Birch trees they are considered choice of trees for landscape too. The substantial Birch trees grows well in all soils due to which they are used as screen or window break. Moreover, due to hard bark they are also used in carpentry and aquatic industry. It is also used in cosmetic products. The birch bark extract may be used in hair conditioners and shampoos. ${ }^{27-29}$

\section{Physical properties of betulin}

Standard betulin has weak water solubility, thus it requires modification for better cellular uptake and desired activity however its derivatives like betulin diacetate (BDA) and betulin dipropionate (BDP) possess greater water solubility as compared to betulin. ${ }^{32,33}$ Therefore, betulin still remains relevant in synthesizing compounds with higher solubility pattern that are considered more biologically active (Table 1) (Figure 1). ${ }^{34}$

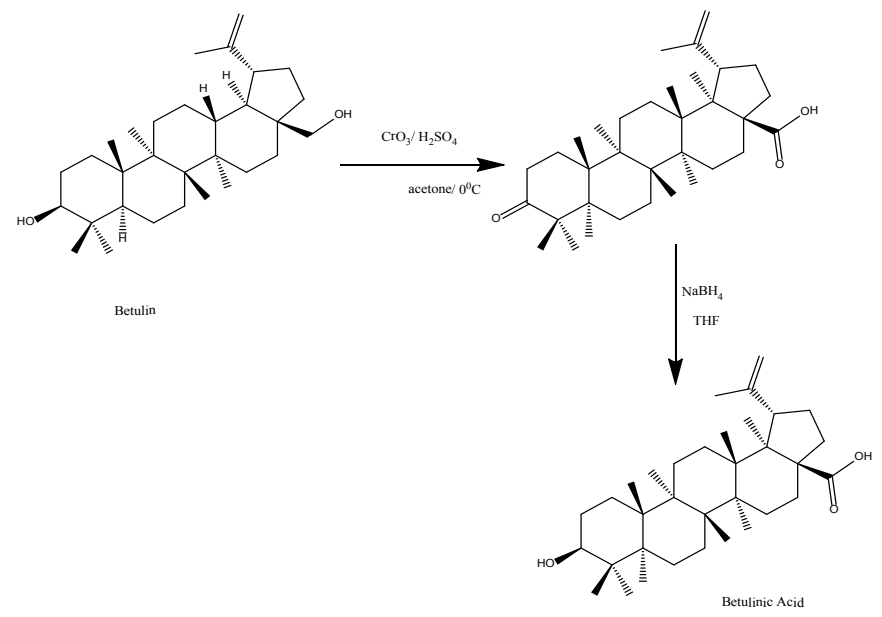

Figure I Represents the preparation of betulinic acid from betulin. ${ }^{7-11}$ 
Table I Represents the physical properties of betulin. ${ }^{1,30,31}$

\begin{tabular}{|c|c|c|}
\hline I & Chemical formula & $\mathrm{C}_{30} \mathrm{H}_{50} \mathrm{O}_{2}$ \\
\hline \multirow[t]{4}{*}{2} & Synonyms & Betulin, \\
\hline & & Betulinol, \\
\hline & & lup-20(29)-en-3 alpha, 28,30-triol, \\
\hline & & lup-20(29)-ene3alpha,28-diol \\
\hline 3 & Appearance & White, crystalline powder \\
\hline 4 & Molar mass & $442.7 \mathrm{~g} / \mathrm{mol}$ \\
\hline 5 & Melting point & $256-257^{\circ} \mathrm{C}$ (lit.) \\
\hline 6 & Solubility & Alcohol, chloroform, benzene \\
\hline 7 & Heat capacity & $80-350 \mathrm{~K}$ \\
\hline
\end{tabular}

\section{Occurrence of betulin in nature}

Betulin has long been explored by research scientist because of the fact that it has anticancer properties ${ }^{35,36}$ and its derivative Betulinic acid is favored due to its anti-HIV activity. ${ }^{12,6,37}$ As mentioned in Figure 1: betulin has three most prominent positions where chemical modifications can be easily accomplished, namely primary hydroxyl group at position $\mathrm{C}-28$, secondary hydroxyl group at position $\mathrm{C}-3$, and alkene moiety at position $\mathrm{C}-20$. The bio-chemical modifications at positions $\mathrm{C}-28$ of the parent structure of betulin produces betulinic acid. ${ }^{12,27,38-41}$ The chief source of Betulin is bark of Birch trees, belonging to family Betulaceae the family of flowering plants. Mostly placed in order Fagales, it can also be placed in order Betulales. The sub-families include Betuloideae genera Betula (birch), Alnus (alder) and Coryloideaegenera Carpinus (hornbeam), Corylus (hazel), Ostrya and Ostryopsis. ${ }^{42-44}$ Betulin, a pentacyclictriterpenoid is derived from linear hydrocarbon squalene. ${ }^{31}$ Triterpenes have three main classes oleane, ursane and lupane triterpenes. Lupane family comprises betulin, betulinic acid, lupeol. ${ }^{6,45}$ Triterpenes are used as traditional herbal medicine and the esters of betulin and fatty acids are used in the production of cosmetics and as plasticizers for PVC (Table 2). ${ }^{31,46}$

Table 2 List of plants possessing betulin

\begin{tabular}{|c|c|c|c|c|}
\hline S. no & Name of plant & Family of plant & Part of plant & Reference \\
\hline I & Betula pumila & Betulaceae & Bark & 47 \\
\hline 2 & Betula pendula(silver birch) & Betulaceae & Bark & $35,47-51$ \\
\hline 3 & Betula jacquemontii & Betulaceae & Bark & 47 \\
\hline 4 & Betula pubescens & Betulaceae & Bark & 29,47 \\
\hline 5 & Betula platphylla & Betulaceae & Bark & 29,47 \\
\hline 6 & Betula papyrifera(paper birch) & Betulaceae & Bark & $12,30,47,52$ \\
\hline 7 & Betula nana & Betulaceae & Bark & 47,53 \\
\hline 8 & Betula nigra & Betulaceae & Bark & 47 \\
\hline 9 & Betula lente & Betulaceae & Bark & 47,54 \\
\hline 10 & Betula alba & Betulaceae & Bark & 29,49 \\
\hline 11 & Betula occidentalis & Betulaceae & Bark & 55 \\
\hline 12 & Platanus acerifolia & Platanaceae & Bark & 56 \\
\hline 13 & Sambucus nigra & Adoxaaceae & Bark & 57 \\
\hline 14 & Olea europeae & Oleaceae & Bark & 58 \\
\hline 15 & Aldus subcordata & Betulaceae & Bark & 59,60 \\
\hline 16 & Ziziphus jujube & Rhamnaceae & Bark & 59,61 \\
\hline 15 & Atracty liscarduus & Asteraceae & Aerial parts of plant & 59,62 \\
\hline 16 & Platanus hypbrida & Platanaceae & Bark & $59,63,64$ \\
\hline 17 & Platanus hyspanica & Platanaceae & Bark & 48 \\
\hline 18 & Nerium oleander & Apocynaceae & Leaves & 8 \\
\hline 19 & Dillenia indica & Dilleniaceae & Stem bark & 2,12 \\
\hline 20 & Tectona grandis & Verbenaceae & Stem bark & 2 \\
\hline 21 & Alangium salvifolium & Cornaceae & Seeds & $65-67$ \\
\hline 22 & Alstonia scholaris & Apocynaceae & Stem bark & 68 \\
\hline 23 & Cornus macrophylla & Cornaceae & Stem bark & $66-69$ \\
\hline 24 & Plumeria obtusa & Apocynacae & Leaves & $70-72$ \\
\hline
\end{tabular}


Table Continued....

\begin{tabular}{lllll}
\hline S. no & Name of plant & Family of plant & Part of plant & Reference \\
\hline 25 & Astercantha longifolia & Acanthaceae & Aerial parts of plant & 73 \\
26 & Aerva lanata & Amaranthaceae & Flower, leaf & 74 \\
27 & Quercus suber & Fagaceae & Bark & 75,76 \\
28 & Acacia mellifera & Fabaceae & Bark & 77 \\
29 & Celtis philippinensis & Cannabaceae & Twigs & 78,79 \\
30 & Coccoloba acrostichoides & Polygonaceae & Aerial parts & 80,81 \\
31 & Anemone raddeana & Ranunculaceae & Roots & 82,83 \\
32 & Diospyros leucomelas & Ebenaceae & Leaves & 29,84 \\
33 & Ziziphus vulgaris & Rhamnacae & Seeds & 29,84 \\
34 & Trochodendron aralioides & Trochodendraceae & Bark & 29,84 \\
35 & Torenia concolor & Scrophulariaceae & Flower & $85-87$ \\
36 & Belamcanda chinensis & Iridaceae & Root & 88 \\
37 & Chaenomeles sinensis & Rosaceae & Fruit & 89,90 \\
\hline 38 & Cyrtomium fortumei & Dryopteridaceae & Rhizomes & 91 \\
\hline
\end{tabular}

\section{Pharmacological studies}

Betulin, as we all known till now possess vast pharmacological properties including choleritic, antihelmintic, powerful prophylactic, anti-HIV, antimutagene agent, antiviral, anti-fungal, anti-leukemia, anti-leishmanial, anti-inflammatory, immunemodulator activities. The latest research suggests some of the major pharmacological properties as discussed below.

\section{Anti-inflammatory and Anti-ulcer activity}

Inflammation is a physiological process which involves pain as a secondary process and its hallmarks include swelling, redness, pain and fever. ${ }^{92}$ Bernard et al. ${ }^{93}$ determined that Betulin and betulinic acid were found to inhibit phospholipase $\mathrm{A} 2$ activity at $5 \mathrm{M}$ concentrations by $30 \%$ and $40 \%$ respectively. ${ }^{93}$ It has also been demonstrated to exhibit inhibitory effects on nitric oxide (NO) and prostaglandin E2 production in mouse macrophages ${ }^{94}$ According to the latest research done by Singh et al. ${ }^{2}$ stem bark extract of Dillenia indica f. elongata (Miq.) Miq.showed significant $(\mathrm{P}<0.01)$ anti-inflammatory activity in formalin and carrageen an induced inflammation models. ${ }^{12}$ Moreover, Betulonic acid exhibited antiulcer action exceeding that of Venter preparation for the models if affection of mucous coat of stomach in rats caused by indomethacin and aspirin with the dose of $50 \mathrm{mg} / \mathrm{kg} .{ }^{95}$

\section{Anti-diabetic}

Diabetes is a metabolic disorder associated with abnormalities in insulin production or secretion along with modifications in carbohydrate, fat and protein metabolism. ${ }^{96,97}$ In accordance to, Riya et al. ${ }^{74}$ determined the presence of betulin, alpha amyrin and beta sitosterol in flower, leaf and roots of Aerva lanata. ${ }^{7,98}$ However, there are reports that betulin is useful in treatment of diabetes. ${ }^{99,100} \mathrm{As}$ $70 \%$ ethanolic extract (ALE) for 21 days in STZ-induced diabetic rat demonstrated that ALE was successful in refining postprandial hyperglycemia in sucrose-loaded normal and STZ diabetic rats, through its promising alpha glucosidase inhibitory potential. ${ }^{101,102}$ Agarwal et al. ${ }^{101}$ reported that the alkaloid-enriched fraction of root of Aervalanata possesses anti-hyperglycemic potential in streptozotocinnicotinamide-induced type II diabetic rats. ${ }^{103}$

\section{Anti-bacterial and anti-microbial activity}

Bacterial infections alone are the cause of around two million deaths globally and it is found that bacterial pathogens probably infect more than one-third of the population around the world. ${ }^{104}$

In accordance to Valterová et al. ${ }^{103}$ the antibacterial activity of C-3 substituted derivatives of betulin with respect to a number of bacteria (Staphylococcus aureus, Staphylococcus faecalis and Staphylococcus beta haemolyticus) was depicted. ${ }^{105}$ Furthermore, Hess et al., ${ }^{104}$ concluded that Betulinic acid has been found to be inactive against Staphylococcus aureus, Escherichia coli, Bacillussubtilis and Micrococcus luteus. ${ }^{106}$

Antimicrobial activity of betulin and its derivatives have been reported against Streptococcus pyogenes with a minimum inhibitory concentration (MIC) of $85 \mu \mathrm{g} / \mathrm{mL}$, and considerable activity has also been observed against other bacteria, i.e. Escherichia coli, Staphylococcus aureus and Enterococcus faecalis. ${ }^{107,108}$

\section{Anti-malarial activity}

Betulin, betulinicacid, ursolic acid and oleanolic acid have also been tested for monitoring antimalarial activity against chloroquine sensitive (T9-96 strain) and resistant (K1 strain) Plasmodium falciparum. It was concluded that betulin was inactive, whereas the others showed moderate activity, betulinicacid being most active in vitro against both strains of $P$. falciparum at IC50 values $19.6 \mathrm{~g} / \mathrm{mL}$ (K1) and $25.9 \mathrm{~g} / \mathrm{mL}$ (T9-96) respectively. ${ }^{109}$ But, in vivo experiments with the NK65 (P. Berghei) model of malaria revealed that betulic acid turned out to be inactive and even toxic at the dose of $250 \mathrm{mg} /$ kg per day. ${ }^{110}$

\section{Anti-viral activity}

According to Karachurina et al., ${ }^{109}$ Betulinbishemiphthalate and betulin dinicotinate stimulate the production of antibody-forming cells in mouse spleen 1.3 and 1.8 times more actively in comparison with the reference. ${ }^{111}$ Adding on, the indicated compounds prevent death of animals from acute radiation sickness. However, Kanamoto et al. ${ }^{110}$ and Baltina et al. ${ }^{111}$ studied anti-viral activity of betulin, betulinic acid 
and its derivatives against influenza A, herpes simplex type 1 (HSV1), influenza FPV/Rostock and ECHO-6 enterovirus. Betulin and betulinicacid were inactive against influenza FPV/Rostock virus on the other hand betulonic acid 3 showed a weak antiviral activity. ${ }^{112,113}$

\section{Anti-hyperlipidaemic activity}

Tang et al. ${ }^{16}$ identified a small-molecule inhibitor of SREBP, betulin, by compound screening. Where SREBP is a major transcription factor that controls the biosynthesis of cholesterol, fatty acid, and triglyceride. ${ }^{114}$ Betulin inhibits SREBP by binding SCAP and making the interaction between SCAP and Insig easier, which leads to the ER-retention of SREBP. Betulin down regulates the genes in cholesterol and fatty acid biosynthesis and decreases the content of cellular lipids, enhances insulin sensitivity, and reduces the development of atherosclerotic plaques. ${ }^{16}$

\section{Anti-cancer activities}

According to the latest research done by Bębenek et al. ${ }^{114}$ Betulin and its semisynthetic derivatives possesses cytotoxic activity toward various cancer cell lines. Experimentation for the antiproliferative activity in vitro against T47D breast cancer, CCRF/CEM leukemia, HL-60 promyelocyticleukemia, SW707 colorectal, murine P388 leukemia, as well as BALB3T3 normal fibroblasts cell lines was done by using betulin and its derivatives. It was discovered that that the derivative of betulin with a propynoyl group at $\mathrm{C}-28$ position, has strong cytotoxic effects against human leukemia (CCRF/CEM) and murine leukemia (P388) cancer cells. ${ }^{115}$

\section{Anti-HIV activities}

Hashimoto et al. ${ }^{115}$ researched that betulin and 3, 28-diacetylbetulin are inactive as anti-HIV agents which confirm the importance of the presence of carboxylic group at $\mathrm{C}-28 .{ }^{116}$ However, betulinic acid and its derivatives have been discovered as a new class of compounds that seem to act as immunomodulator and protect the cells invitro from attack by the HIV virus. ${ }^{117}$ Furthermore, synthetic betulinicacid derivatives, especially 3-alkylamido-3-deoxy-betulinic acid derivatives, inhibit the life cycle of the virus in the infected cells in its early phase hence; defend the surrounding cells from HIV proliferation. ${ }^{118}$ Also, one must take into consideration that anti-HIV activity increases in amides and peptides of betulic and betulonic acids. ${ }^{119,120}$

\section{Conclusion}

It is commendable that betulin is found in 200 different types of plants indefinitely distributed across the plantae kingdom and owes to diverse pharmacological activities. But despite of its easy and free availability in nature, betulin and its derivatives are still not empathized in pharmaceutical industries. The good side of picture is that the isolation of betulin is not a tough job and need not require complex analytical techniques. The tool of biotechnology can further be applied to gain maximum pharmaceutical advantages of betulin. Due to the fact that it is a compound obtained from plant source and possess vast significant pharmacological properties it can be utilized in herbal pharmaceutical industries with a new concept of nano-medicine. Having minimal side effects gives betulin an edge over other compounds and plant extracts containing betulin are also of equal importance for possessing signified efficacy resulting in decreased level of toxicity. At last, it seems that betulin requires our re-attention so that with the help of growing analytical techniques we can produce its new derivatives which could be a boon to society for treating various ailments.

\section{Acknowledgements}

The authors are very thankful to the Dr. Charanjit Singh for sparing his valuable time for this article.

\section{Conflict of interest}

The author declares no conflict of interest.

\section{References}

1. Lesellier E, Destandau E, Grigoras C, et al. Fast separation of triterpenoids by supercritical fluid chromatography/evaporative light scattering detector. J Chromatogr A. 2012;1268:157-165.

2. Singh AP, Aeri V. Physico-chemical parameters and HPTLC fingerprinting profile Dilleniaindica MIQ. F. Elongata (MIQ.) and Tectonagrandis LINN. With reference to betulin. Int J Pharm Bio Sci. 2016;7(1):217-221.

3. Szakiel A, Pączkowski C, Pensec F, et al. Fruit cuticular waxes as a source of biologically active triterpenoids. Phytochem Rev. 2012;11(23):263-284.

4. Mullauer FB, Kessler JH, Medema JP. Betulinic acid, a natural Compound with potent anticancer effects. Anticancer Drugs. 2010;21(3):215-227.

5. Laszczyk M, Jäger S, Simon-Haarhaus B, et al. Physical, chemical and pharmacological characterization of a new oleo gel-forming triterpene extract from the outer bark of birch (betulae cortex). Planta Med. 2006;72(15):1389-1395.

6. Chichewicz RH, Kouzi SA. Chemistry, biological activity and chemotherapeutic potential of betulinic acid for the prevention and treatment of cancer and HIV infection. Med Res Rev. 2004;24(1):90-114

7. Alakurtti S, Mäkelä T, Koskimies S, et al. Pharmacological properties of the ubiquitous natural product betulin. Eur J Pharm Sci. 2006;29(1):113 .

8. Tolstikov GA, Flekhter OB, Shultz EE, et al. Betulin and its derivatives. Chemistry and biological activity. Chemistry for Sustainable Development. 2005;13:1-29.

9. Hayek EWH, Moche W, Sauter F. A bicentinial of betulin. Phytochemistry. 1989;28(9):2229-2242.

10. Sarek J, Klinot J, Brazinova S, et al. New Lupane Derived Compounds with Pro-Apoptotic Activity in Cancer Cells: Synthesis and StructureActivity Relationships. J Med Chem. 2003;46(25):5402-5415.

11. Kim DSHL, Che Z, Nguyen T, et al. A Concise Semi-Synthetic Approach to Betulinic Acid from Betulin. Synthetic Communications. 1997;27(9):1607-1612

12. SinghAP, Brindavanam NB. A validated HPLC method for the determination of betulin in the stem bark of Tectona grandis Linn. IJPSR. 2016;7(2):719-723.

13. Chaturvedi PK, Bhui K, Shukla Y. Lupeol: connotations for chemoprevention. Cancer Lett. 2008;263(1):1-13.

14. Fulda S. Betulinic acid for cancer treatment and prevention. Int J Mol Sci. 2008;9(6):1096-1107.

15. Jäger S, Laszczyk MN, Scheffler A. A preliminary pharmacokinetic study of betulin, the main pentacyclic triterpene from extract of outer bark of birch (Betulae alba cortex). Molecules. 2008;13(12):3224-3235. 
16. Tang JJ, Li JG, Qi W, et al. Inhibition of SREBP by a small molecule, betulin, improves hyperlipidemia and insulin resistance and reduces atherosclerotic plaques. Cell Metab. 2011;13(1):44-56.

17. Gachet MS, Kunert O, Kaiser M, et al. Antiparasitic compounds from Cupania cinerea with activities against Plasmodium falciparum and Trypanosoma brucei rhodesiense. J Nat Prod. 2011;74(4):559-566.

18. Reyes CP, Núnez MJ, Jiménez IA, et al. Activity of lupine triterpenoids from Maytenus species as inhibitors of nitric oxide and prostaglandin E2 Bioorg Med Chem. 2006;14(5):1573-1579.

19. Liwei $\mathrm{Fu}$, Zhang $\mathrm{S}$, Li N, et al. Three new triterpenes from Nerium oleander and biological activity of the isolated compounds. J Nat Prod. 2005;68(2):198-206.

20. Kashiwada Y, Chiyo J, Ikeshiro Y, et al. 3,28-Di-O-(dimethylsuccinyl)betulin isomers as anti-HIV agents1. Bioorganic \& Medicinal Chemistry Letters. 2001;11(2):183-185.

21. Kanamoto T, Kashiwada Y, Kanbara K, et al. Anti-Human Immunodeficiency Virus Activity of YK-FH312 (a Betulinic Acid Derivative), a Novel Compound Blocking Viral Maturation. Antimicrobial Agents Chemotherapy. 2001;45(4):1225-1230.

22. Pisha E, Chai H, Lee IS, et al. Discovery of betulinic acid as a selective inhibitor of human melanoma that functions by induction of apoptosis. Nature Medicine. 1995;1:1046-1051.

23. Gao Y, Xu H, Lu Z, et al. Quantitative determination of steroids in the fruiting bodies and submerged-cultured mycelia of Inonotusobliquus. Se Pu. 2009;27(6):745-749.

24. Tilford Gregory L. Edible and Medicinal Plants of the West. USA: Mountain Press; 1997. 256 p.

25. Yogeeswari P, Sriram D. Betulinic acid and its derivatives: a review on their biological properties. Curr Med Chem. 2005;12(6):657-666.

26. Quintão NL, Rocha LW, Silva GF, et al. Contribution of $\alpha, \beta-$ Amyrenone to the Anti-Inflammatory and Antihypersensitivity Effects of Aleurites moluccana (L.) Willd. BioMed Research International. 2014;2014:11.

27. English Names for Korean Native Plants. Pocheon: Korea National Arboretum; 2015. 373 p.

28. Maurya SK, Devi S, Pandey VB. Fitother. 1989;60:468.

29. Patočka J. Biologically active pentacyclic triterpenes and their curren medicine signification. Journal of Applied Biomedicine. 2003;1(1):7-12.

30. Yash VF, Kokurina N Yu, VN Larina, et al. Physicochemical Properties of Betulin and $\mathrm{CO}_{2}$ Extract from Birch Bark. Russian Journal of Physical Chemistry B. 2014;8(8):1100-1109.

31. Akihisa T, Takamine Y, Yoshizumi K, et al. Microbial transformation of two lupane-type triterpenes and anti-tumor-promoting effects of the transformation products. J Nat Prod. 2002;65(3):278-282.

32. Shakhtshneider TP, Kuznetsova SA, Zamay AS, et al. New composites of betulin esters with arabinogalactan as highly potent anti-cancer agents. Nat Prod Res. 2015;30(12):1382-1387.

33. Drag-Zalesinska, Kulbacka J, Saczko J, et al. Esters of betulin and betulinic acid with amino acids have improved water solubility and are selectively cytotoxic toward cancer cells. Bioorg Med Chem Lett. 2009;19(16):4814-4817.

34. Drag M, Surowiak P, Drag-Zalesinska M, et al. Comparision of the Cytotoxic Effects of Birch Bark Extract, Betulin and Betulinic Acid towards Human Gastric Carcinoma and Pancreatic Carcinoma Drugsensitive and Drug-Resistant Cell Lines. Molecules. 2009;14(4):16391651 .
35. Pettit GR. Progress in the Discovery of Biosynthetic Anticancer Drugs. $J$ Nat Prod. 1996;59(8):812-821.

36. Pospíšil M, Kovář P, Vácha R, et al. Study of the betulin molecule in water environment; $\mathrm{ab}$ initio and molecular simulation calculations. $J$ Mol Model. 2012;18(1):367-376.

37. Hata K, Hori K, Ogasawara H, et al. Anti-leukemia activities of lup-28al-20(29)-en-3one, a lupine triterpene. Toxicol Lett. 2003;143(1):1-7.

38. Csuk R, Schmuck K, Schafer R. A practical synthesis of betulinic acid. Tetrahedron Letters. 2006;47(49):8769-8770.

39. Csuk R. Betulinic acid and its derivatives: a patent review (2008-2013). Expert Opin Ther Pat. 2014;24(8):913-923.

40. Bache M, Bernhardt S, Passin S, et al. Betulinic acid derivatives NVX-207 and B10 for treatment of glioblastoma-an in vitro study of cytotoxicity and radiosensitization. Int J Mol Sci. 2014;15(11):1977719790.

41. Baratto LC, Porsani MV, Pimentel IC, et al. Preparation of betulinic acid derivatives by chemical and biotransformation methods and determination of cytotoxicity against selected cancer cell lines. Eur $J$ Med Chem. 2013;68:121-131.

42. Nick A, Wright AD, Rali T, et al. Antibacterial triterpenoids from Dillenia papuana and their structure-activity relationships. Phytochemistry. 1995;40(6):1691-1695.

43. Aponte JC, Vaisberg AJ, Rojas R, et al. Isolation of Cytotoxic Metabolites from Targeted Peruvian Amazonian Medicinal Plants. J Nat Prod. 2008;71(1):102-105.

44. Zuo GY, Wang GC, Zhao YB, et al. Screening of Chinese medicinal plants for inhibition against clinical isolates of methicillin-resistant Staphylococcus aureus (MRSA). Journal of Ethnopharmacology. 2008;120(2):287-290.

45. Flekhter OB, Medvedeva NI, Karachurina LT, et al. Synthesis and pharmacological activity of betulin, betulinicacid and allobetulin esters Pharmaceutical Chemistry Journal. 2005;39(8):401-404.

46. Xi J, Chang Q, Chan $\mathrm{CK}$, et al. Formulation development and bioavailability evaluation of a self-nanoemulsified drug delivery system of oleanolic acid. AAPS PharmSciTech . 2009;10(1):172-182.

47. Keinänen M, R Julkunen-Tiitto, M Rousi, et al. Taxonomic implications of phenolic variation in leaves of birch (BetulaL.) species. Biochemical Systematics and Ecology. 1999;27(3):243-254.

48. Fujioka T, Kashiwada Y, Kilkuskie RE, et al. Anti-AIDS Agents, 11. Betulinic Acid and Platanic Acid as Anti-HIV Principles from Syzigium claviflorum, and the Anti-HIV Activity of Structurally Related Triterpenoids. J Nat Prod. 1994;57(2):243-247.

49. Hybelbauerova S, Sejbal J, Dracínský M, et al. Chemical Constituent of Stereum subtomentosum and Two Other birch-associated basidiomycetes:an interspecies comparative study. Chem Biodivers. 1999;5(5):743-750.

50. Galgon T, Hoke D, Dräker B. Identification and Quantification of Betulinic Acid. Phytochemical Analysis. 1999;10(4):187-190.

51. Zhao G, Yan W, Cao D. Simultaneous determination of betulin and betulinic acid in white birch bark using RP-HPLC. J Pharm Biomed Anal. 2007;43(3):959-962.

52. Stritch L. Betula nana. IUCN Red List of Threatened Species. 2014.

53. Eickwort George C, Matthews Robert W, Carpenter James. Observations on the Nesting Behavior of Megachile rubi and M. texana with a Discussion of the Significance of Soil Nesting in the Evolution of Megachilid Bees (Hymenoptera: Megachilidae). Journal of the Kansas Entomological Society. 1981;54(3):557-570. 
54. Hunn Eugene S. Nch'i-Wana, The Big River: Mid-Columbia Indians and Their Land. 1990. $352 \mathrm{p}$

55. Thai QD, Tchoumtchoua J, Makropoulou M, et al. Phytochemical study and biological evaluation of chemical constituents of Platanusorientalis and Platanus $\times$ acerifolia buds. Phytochemistry. 2016;130:170-181.

56. Lawrie W, McLean J, Paton AC. Triterpenoids in the bark of elder (Sambucus nigra). Phytochemistry. 1964;3(2):267-268.

57. Hashmi MA, Khan A, Muhammad Hanif, et al. Traditional Uses, Phytochemistry, and Pharmacology of Olea europaea (Olive). EvidenceBased Complementary and Alternative Medicine. 2015;2015:29.

58. Matyukhina LG, Shmukler VS, Ryabinin AA. Obshch Khim Zh. 1965;35:579.

59. Maurya SK, Devi S, Pandey VB, et al. Fitoterapia. 1989;60:468.

60. Kundu B, Barik BR, Mondal DN. Phytochemistry. 1989;28:3155.

61. Melek FR, Ranwan AS, Ahmed AA, et al. Chemical constituents of two Centaurea species. Farmazie. 1989;44:735.

62. Recio CM, Giner RM, S Manez, et al. Investigations on the steroidal anti-inflammatory activity of triterpenoids from Diospyros leucomelas. Planta Med. 1995;61(1):9-12.

63. Okamoto Y Takeya, Kagawa Y, Kotani E. Iron (III) Picolinate-Induced Oxygenation and Subsequent Rearrangement of Triterpenoid Derivatives with Hydrogen Peroxide. Chemical and Pharmaceutical Bulletin. 2000;48(1):120-125

64. Siddiqui S, Hafeez F, Begum S, et al. Nut Prod. 1986;49:1086.

65. Mukherjee. Bull. Bot. Surv. India; 1969. 10:330.

66. Bennet Fl. Grewia salvifolia Lf. 1979;409:1781.

67. Clarke in Hook. f., Fl. Brit. India; 1879. 2:741.

68. Mem Wern. Nat Hist Soc. 1810;1:76.

69. Prain. Bengal Pl. 1903;2:672.

70. Siddiqui S, Siddiqui BS, Naeed A, et al. Three pentacyclic triterpenoids from the leaves of Plumeria obtuse. J Nat Prod. 1990;53:1332-1336.

71. Siddiqui S, Siddiqui BS, Naeed A, et al. Pentacyclic triterpenoid from the leaves of Plumeria obtusa. Photochemistry. 1992;31(12):4279-4283.

72. Siddiqui BS, Naeed A, Begum S, et al. Minor iridoids from the leaves of Plumeria obtusa. Photochemistry. 1994;37(3):769-771.

73. Quasim C, Dutta NL. Reported the presence of stigmasterol in the root of Asteracantha longifolia Nees. J Indian Chem Soc. 1967;44:82.

74. Riya MP, Antu KA, Pal S, et al. Antidiabetic property of Aerva lanata (L.) Juss. ex Schult. is mediated by inhibition of alpha glucosidase, protein glycation and stimulation of adipogenesis. J Diabetes. 2013;7(4):548561.

75. Vidhya R, Udayakumar R. Phytochemical screening and evaluation of in vitro Haemolytic Thrombolytic and anti-inflamatory activities of Aerva (L.). Indo American Journal of Pharmaceutical Research. 2016;6(7):5965-5973.

76. Vidhya R, Udayakumar R. Antibacterial potential of different parts of Aerva lanata (L.) against some selected clinical isolates from urinary tract infections. Br Microbiol Res J. 2015;7(1):35-47.

77. Sadiq MB, Hanpithakpong W. Screening of photochemical and in vitro evaluation of antibacterial and antioxidant activities of leaves, pods and bark extracts of Acacia nilotica (L.) Del. Industrial Crops and Products. $2015 ; 77: 873-882$

78. Likhitwitayawuid K, Angerhofer CK, Cordell GA, et al. Cytotoxic and antimalarial bisbenzylisoquinolinealka-loids from Stephaniaerecta. $J$ Nat Prod. 1993;56(1):30-38.
79. Seo EK, Kim NC, Mi Q, et al. Macharistol, a new cytotoxic cinnamylphenol from the stem of Machaerium aristulatum. J Nat Prod. 2001;64:1483-1485.

80. Wagner H, Bladt S, Zgainski EM. Plant drug analysis. 1st ed. Turkey: Springer Verlag; 1984

81. Wu FE, Zu ZQ. Studies on the chemical constituents of the Chinese medicinal herb Anemone raddeana regel. Acta Chimica Sinica. 1984;42:253-599.

82. Wu FE, Koike $\mathrm{K}$, Ohmoto $\mathrm{T}$, et al. Saponins from Chinese folk medicine 'zhujiexiangfu,' Anemone raddeana regel. Chem Pharm Bull. 1989;37(9):2445-2447.

83. Zhang JM, Li BG, Wang MK, et al. Oleanolic acid basedbisglycosides from Anemoneraddeana regel. Photochemistry. 1997;45:1031.

84. Król SK, KieBbus M. Comprehensive Review on Betulin as a Potent Anticancer Agent. BioMed Research International. 2014;2015:11.

85. Ma XH, Zhao YC, Yin L, et al. Studies on the preventive and therapeutic effects of ursolic acid on acute hepatic injury in rats. Yao Xue Xue Bao. $1986 ; 21(5): 332-335$

86. Tokuda $\mathrm{H}$, Ohigashi $\mathrm{H}$, Koshimizu $\mathrm{K}$, et al. Inhibitory effects ofursolic acid and oleanoic acid on skin tumor promotion by $12-\mathrm{O}$ tetradecanoylphorbol-13-acetate. Cancer Lett. 1986;33(3):279-285.

87. Pisha EH, Chai, Lee IS, et al. Discovery of betulinic acid as a selective inhibitor of human melanoma that functions by induction of apoptosis. Nat Med. 1995;1(10):1046-1051.

88. Liu M, Yeng S, Jin L, et al. Chemical constituents of the ethyl acetate extract of belamcanda chinensis (L.) DC roots and their antitumor activities. Molecules. 2012;17:6156-6169.

89. Lianna S, Yongfu H, Guo Xuemin, et al. Studies on the chemical constituents of Chaenomeles sinensis (Thouin.) Koehne. Academic Journal of Second Military Medical University. 1999;20(10):752-754

90. LIU Ji-yan, Liuxue-qing, Huheng-bin. (School of Chemical and Environmental Engineering, Jianghan University, Wuhan 430056, China). Study on Extraction Technology of Polysaccharide from Chaenomeles Sinensis. Chemistry \& Bioengineering. 2008-11.

91. Yang S, Liu M. Discovery and antitumor activities of constituents from Cyrtomium fortumei (J.) Smith rhizomes. Chemistry Central Journal. 2013:7-24.

92. Alam MB, Chowdary NS, Mazumder MEH. Antimicrobial and toxicity study of different Fractions of Dillenia indica (L) Bark Extract. IJPSR. 2011;2(4):860-866.

93. Bernard P, Scior T, Didier B, et al. Ethnopharmacology and bioinformatic combination for leads discovery: application to phospholipase A2 inhibitors. Photochemistry. 2001;58(6):865-874.

94. Flekhter OB, Nigmatullin LR, Baltina LA Khim. Farm. Zh. 2002;36:19.

95. Das SK, Elbein SC. The Genetic Basis of Type 2 Diabetes. Cell science. 2006;2(4):100-131.

96. Wild S, Roglic G, Green A, et al. Global prevalence of diabetes: estimates for the year 2000 and projections for 2030. Diabetes Care. 2004;27(5):1047-1053

97. Riya MP, Antu KA, Pal S, et al. Nutraceutical potential of Aerva lanata (L.) Juss. ex Schult ameliorates secondary complications in streptozotocin-induced diabetic rats. J Diabetes. 2013;5:2086-2095.

98. Dehelean C, Soica C, Ledet I, et al. Study of the betulin enriched birch bark extracts effects on human carcinoma cells and ear inflammation. Chemistry Central Journal. 2012;6(137):1-9.

99. Mullauer FB, Kessler JH, Medema JP. Betulin Is a Potent Anti-Tumor Agent that Is Enhanced by Cholesterol. PLoS One. 2009;4:1-6. 
100. Riya MP, Antu AK. Nutraceutical potential of Aerva lanata (L.)Juss. Ex Schult ameliorates secondary complications in streptozotocin-induced diabetic rats. Food \& Function. 2014;9:2086-2095.

101. Agrawal R, Sethiya NK, Mishra SH. Antidiabetic activity of alkaloids of Aerva lanata roots on streptozotocin-nicotinamide induced type-II diabetes in rats. Pharm Biol. 2013;51:635-642.

102. Monaghan RL, Barrett JF. Antibacterial drug discovery-then, now and the genomics future. Biochem Pharmacol. 2006;71(7):901-909.

103. Valterová, Klinot J, Vystrèil A, et al. Preparation and antibacterial activity of di, triand tetraoic acids derived from 3,4-secolupane. Collect Czech Chem Commun. 1983;48(2):649.

104. Hess SC, Brum RL, Honda NK, et al. Antibacterial activity and phytochemical analysis of Vochysiadivergens (Vochysiaceae). $J$ Ethnopharmacol. 1995;47(2):97-100.

105. Prachayasittikul S, Saraban P, Cherdtrakulkiat R, et al. New bioactive triterpenoids and antimalarial activity of Diospyros rubra Lec. Excli Journal. 2010;9:1-10.

106. Yli Kauhaluoma J, Koskimies S, Alakurtti S, et al. Betulin derived compounds useful as antibacterical agents. 2007.

107. Steele JC, Warhurst DC, Kirby GC, et al. In vitro and in vivo evaluation of betulinic acid as an antimalarial. Phytother Res. 1999;13(2):115-119.

108. Steele JCP, Warhurst DC, Kirby GC, et al. In vitro and In vivo evaluation of betulinic acid as an antimalarial. Phytother Res. 1999;13(2):115-119.

109. Karachurina LT, Flekhter OB, Sapozhnikova TA, et al. VI, Mezhdunar. konf. Bioantioksidant, Moscow, Russia.

110. Kanamoto T, Kashiwada Y, Kanbara K, et al. Anti-human immunodeficiency virus activity of YK-FH312 (a betulinicacid derivative), a novel compound blocking viral maturation. Antimicrob
Agents Chemther. 2001;45(4):1225-1230.

111. Baltina LA, Flekhter OB, Nigmatullina LR, et al. Lupane triterpenes and derivatives with antiviral activity. Bioorg Med Chem Lett. 2003;13(20):3549-3552.

112. Pavlova NI, Savinova OV, Nikolaeva SN, et al. Antiviral activity of betulin, betulinic and betulonic acids against some enveloped and nonenveloped viruses. Fitoterapia. 2003;74(5):489-492.

113. Goldstein JL, DeBose Boyd RA, Brown MS. Protein sensors for membrane sterols. Cell. 2006;124(1):35-46.

114. Bębenek E, Tomanek MK. New acetylenic derivatives of betulin and betulone, synthesis and cytotoxic activity. Med Chem Res. 2017;26(1):1-

115. Hashimoto F, Kashiwada Y, Cosentino LM, et al. Anti-AIDS agents: XXVII. Synthesis and anti-HIV activity of betulinic acid and dihydrobetulinic acid derivatives. Bioorg Med Chem. 1997;5(12):21332143.

116. Soler F, Poujade C, Evers M, et al. Betulinic acid derivatives: a new class of specific inhibitors of human Immunodeficiency virus type 1 entry. $J$ Med Chem. 1996;39(5):1069-1083.

117. Kashiwada Y, Chiyo J, Ikeshiro Y, et al. Synthesis and anti-HIV activity of 3-alkylamido-3-deoxy-betulinic acid derivatives. Chem Pharm Bull (Tokyo). 2000;48(9):1387-1390.

118. Pokrovskiy G, Plyasunova OA, Ilicheva TN. Khimiya v interesakhustoichivo gorazvitiya. 2001;9:485.

119. Ilina TV, Semenova EA, Plyasunova OA. Byull. So Ramn. 2002;2(20):180.

120. Pat. 2211843 RF. 2003. 